\title{
Article \\ Experimental Study and Design of Biomass Co-Firing in a Full-Scale Coal-Fired Furnace with Storage Pulverizing System
}

\author{
Xuebin Wang ${ }^{1}$, Zia Ur Rahman ${ }^{1}$, Zhaomin Lv ${ }^{1}$, Yiming Zhu ${ }^{1}$, Renhui Ruan ${ }^{1}$, Shuanghui Deng ${ }^{1}$, Lan Zhang ${ }^{2}$ and \\ Houzhang Tan ${ }^{1, *}$ \\ 1 MOE Key Laboratory of Thermo-Fluid Science and Engineering, Xi'an Jiaotong University, \\ Xi'an 710049, China; wxb005@xjtu.edu.cn (X.W.); 4119999011@stu.xjtu.edu.cn (Z.U.R.); \\ mx1029@stu.xjtu.edu.cn (Z.L.); m10184757920@stu.xjtu.edu.cn (Y.Z.); ruanrenhui@stu.xjtu.edu.cn (R.R.); \\ shdeng@xjtu.edu.cn (S.D.) \\ 2 Henan Province Boiler Pressure Vessel Safety Inspection Institute, Zhengzhou 450016, China; \\ zhengshijie1997@stu.xjtu.edu.cn \\ * Correspondence: tanhz@mail.xjtu.edu.cn
}

check for updates

Citation: Wang, X.; Rahman, Z.U.; Lv, Z.; Zhu, Y.; Ruan, R.; Deng, S.; Zhang, L.; Tan, H. Experimental Study and Design of Biomass Co-Firing in a Full-Scale Coal-Fired Furnace with Storage Pulverizing System. Agronomy 2021, 11, 810. https://doi.org/10.3390/ agronomy11040810

Academic Editor: Nicholas Korres

Received: 17 March 2021

Accepted: 14 April 2021

Published: 20 April 2021

Publisher's Note: MDPI stays neutral with regard to jurisdictional claims in published maps and institutional affiliations.

Copyright: (C) 2021 by the authors. Licensee MDPI, Basel, Switzerland. This article is an open access article distributed under the terms and conditions of the Creative Commons Attribution (CC BY) license (https:/ / creativecommons.org/licenses/by/ $4.0 /)$.

\begin{abstract}
Co-firing coal and biomass in existing power plants facilitates influential advancement in the use of renewable energy resources and carbon emissions reduction. Biomass is intended as a $\mathrm{CO}_{2}$-zero net emission because, during its rise, it uses the same fraction of $\mathrm{CO}_{2}$ from the air as that released during its combustion. In addition, the content of nitrogen and sulfur in biomass is lower than in coal. Therefore, the emissions of $\mathrm{NO}_{\mathrm{x}}$ and $\mathrm{SO}_{\mathrm{x}}$ can be minimized by co-firing it with coal. In general, the effect of biomass direct co-firing on safety, pulverizing system performance, furnace efficiency, and $\mathrm{NO}_{x}$ emission in full-scale furnaces is rarely studied. In this study, biomass direct co-firing was carried out in a $55 \mathrm{MW}$ tangentially fired pulverized coal furnace. The effects of biomass co-firing on safety, the performance of the pulverizing system, furnace efficiency, and pollutant emissions (unburned carbon and $\mathrm{NO}_{\mathrm{x}}$ ) are studied. The results show that the blending of biomass fuel with less than $20 \%$ of coal has no issue with respect to auto-ignition and safety. The performance of the pulverizing system is affected up to a certain limit due to the difficulty of grinding the biomass particles into required fineness. The biomass co-firing up to $20 \%$ is feasible, but greater than this percentage will severely affect the furnace efficiency. The co-firing of biomass enhanced the $\mathrm{NO}_{\mathrm{x}}$ reduction significantly and further improved the performance of the SNCR process. This study could provide guidance for the application of biomass co-firing in industrial furnaces.
\end{abstract}

Keywords: biomass co-firing; furnace efficiency; mill performance; $\mathrm{NO}_{\mathrm{x}}$ emission

\section{Introduction}

Coal is the world's largest source of energy for electricity production [1]. Coal contributes more than $38 \%$ to the production of the world's electricity. However, coal is the world's prominent source of $\mathrm{CO}_{2}$ production [2]. Today, the world is facing major challenges in reducing greenhouse gas (GHG) pollution. All developed and developing countries are making heavy investments to replace conventional fuel with renewable energy resources.

Co-firing biomass has a vital role in achieving these new energy objectives, as it can reduce the potential environmental consequences of fossil fuels combustions [3-6]. In co-firing, greenhouse gasses, such as $\mathrm{CO}_{2}, \mathrm{NO}_{\mathrm{x}}$, and $\mathrm{SO}_{\mathrm{x}}$ can be reduced when replacing a portion of coal with biomass [7-11]. Biomass is intended as a $\mathrm{CO}_{2}$-zero net atmospheric emission because, during its rise, it uses the same fraction of $\mathrm{CO}_{2}$ from the air as that released during its combustion. Despite the usefulness of biomass co-firing, it has a high alkali and chlorine content. Therefore, the burning of $100 \%$ biomass can lead to a severe complication of slagging and corrosion, and this can be circumvented sufficiently when co-firing biomass is used with coal $[12,13]$. 
Relatively rapid advances in co-firing have been carried out worldwide over the past decades, since the 1970s [14].

Several Asian countries, such as Japan, China, and South Korea, have already started co-firing technologies [2]. Wood pellets co-fired with coal are regarded in these regions as the primary source of electricity [15]; Nevertheless, a large part of the wood pellets remains unused for co-firing with biomass. Several concerns have been raised in relation to the production of biomass energy. Such issues include the stable supply of raw materials, the availability of wood products, and the establishment of a supply chain [2].

China is a rich biomass resourceful country, and the potential volume of biomass is about 5 billion tons of coal equivalent, nearly three times that of total current energy use [16]. The development of biomass power in China began in 2004; the first three biomass energy production projects were approved by the National Development and Reform Commission; developed in Shandong, Hebei, and Jiangsu provinces. At the end of 2006, in Dan County, Shandong Province, the project for the development of biomass energy (with a generating unit of $12.5 \mathrm{~kW}$ ) was commissioned [14].

However, the market for the production of biomass power in China is still limited, and the laws and regulations for the production of biomass power are incomplete. Due to scattered materials and long logistics chain, high production costs, outdated equipment, technical immaturity, inadequate raw materials, and extreme investment shortages, the cost of generating biomass energy is higher than that of generating thermal power and hydroelectric power. Consequently, the development of biomass energy in China requires further policy support [16]. Biomass electricity generation involves biomass collection, processing, transport, storage, combustion equipment adaptability, process management, etc. Particularly because it is challenging to design and produce biomass boilers, the investment in imported and domestic equipment is approximately USD 1545.21/kWh and USD $1236.17 / \mathrm{kWh}$, respectively, whereas the investment in thermal power equipment accounts for only $50 \%$ [17].

Several studies have been conducted on the co-firing of biomass with coal and the power trade of biomass. Anes Kazagic et al. [18] assessed the reasonable expectation that under actual operating conditions of a PC large boiler, tested coal/woody biomass/Miscanthus blends could be effectively co-fired without major ash-related issues. However, by increasing the biomass ratio above 15\% the UBC ratio in the ash slag may increase. Larry Baxter [19] presented biomass-coal co-combustion as a short-term, lowrisk, low-cost, clean, renewable energy solution promising to minimize competitive $\mathrm{CO}_{2}$ emissions, lower $\mathrm{SO}_{x}$ and often $\mathrm{NO}_{x}$ emissions, and many social benefits. Although, it has some technical problems, such as fuel supply, processing problems with oxidation, reduced overall performance, and ash deposition. Minsung Choi et al. [20] evaluated the $0-30 \%$ ratio of woody biomass and bituminous coal combustion using woody biomass, and it was found that woody biomass co-fired flames had a higher overall temperature than pure bituminous fuel flames. Rui Luo and Qulan Zhou [21] investigated the impact of carbon ash content, mixing ratio, and oxygen concentration on the biomass-coal interaction. It has been shown that mixtures of coal and biomass burning energy variability are influenced by carbon ash content, and biomass mixing will help to efficiently burn coal with low ash content.

However, some major unresolved issues still need to be addressed, such as co-firing biomass modes, pulverizing methods, safety, storage, economy, pollutant emissions, and the most important is efficiency. Since an efficient, safe, and economic co-firing mode of biomass remains the main requirement for the large-scale use of biomass in China. The aim of this paper is to test the most economical direct mode of co-firing biomass in a full-scale coal-fired power plant of $55 \mathrm{MW}$. Primarily focused on the effect of biomass co-firing on the operating safety of pulverizing and fuel storage systems, the efficiency, and pollutant emissions of power plants. This study could provide guidance for the application of biomass co-firing in industrial furnaces. 


\section{Distribution of Biomass Resource around the Power Plant}

To cope, one of the main challenges, which is very crucial for a productive and sustainable operation of biomass co-firing, is the availability of biomass resources around the plant area. In this study, the distribution of biomass resources is surveyed in a $100 \mathrm{~km}$ area around the power plant location, as shown in Figure 1. The plant is located in Baishui County, which covers Weinan, Yan'an, Tongchuan, and Xi'an. It mainly includes 16 counties and districts, such as Baishui, Huanglong, Fuping, Hancheng, Chengcheng, Heyang, Dali, Hua, Huangling, Luochuan, Fuxian, Yijun, Wangyi, Yintai, Yaozhou, and Yanliang. Baishui County, located in the northeast of Shaanxi province, is in the transition zone between Guanzhong plain and the northern Shaanxi plateau. It is the key point connecting Guanzhong and northern Shaanxi and is named for the Baishui River within the territory. The county has an arable land area of 48,000 hectares, a grain planting area of 34,596 hectares (including spring and autumn), and an apple planting area of 36,666 hectares, earning the reputation of "China's apple town". The capacity of biomass resources is summarized in Table 1. The agricultural statistical data in Table 1 are collected from the government of several counties. When the $55 \mathrm{MW}$ power plant is operated with $100 \%$ coal, it required 0.5 million tons per year. By calculating the biomass requirement for $20 \%$ co-firing with coal, it will be required 0.1 million ton per year while the biomass resources available in $100 \mathrm{~km}$ area around the plant are up to 4 million ton, which is ten times greater than the required resources for co-firing. Furthermore, the heating values and proximate analysis of available biomass resources are portrayed in Table 2.

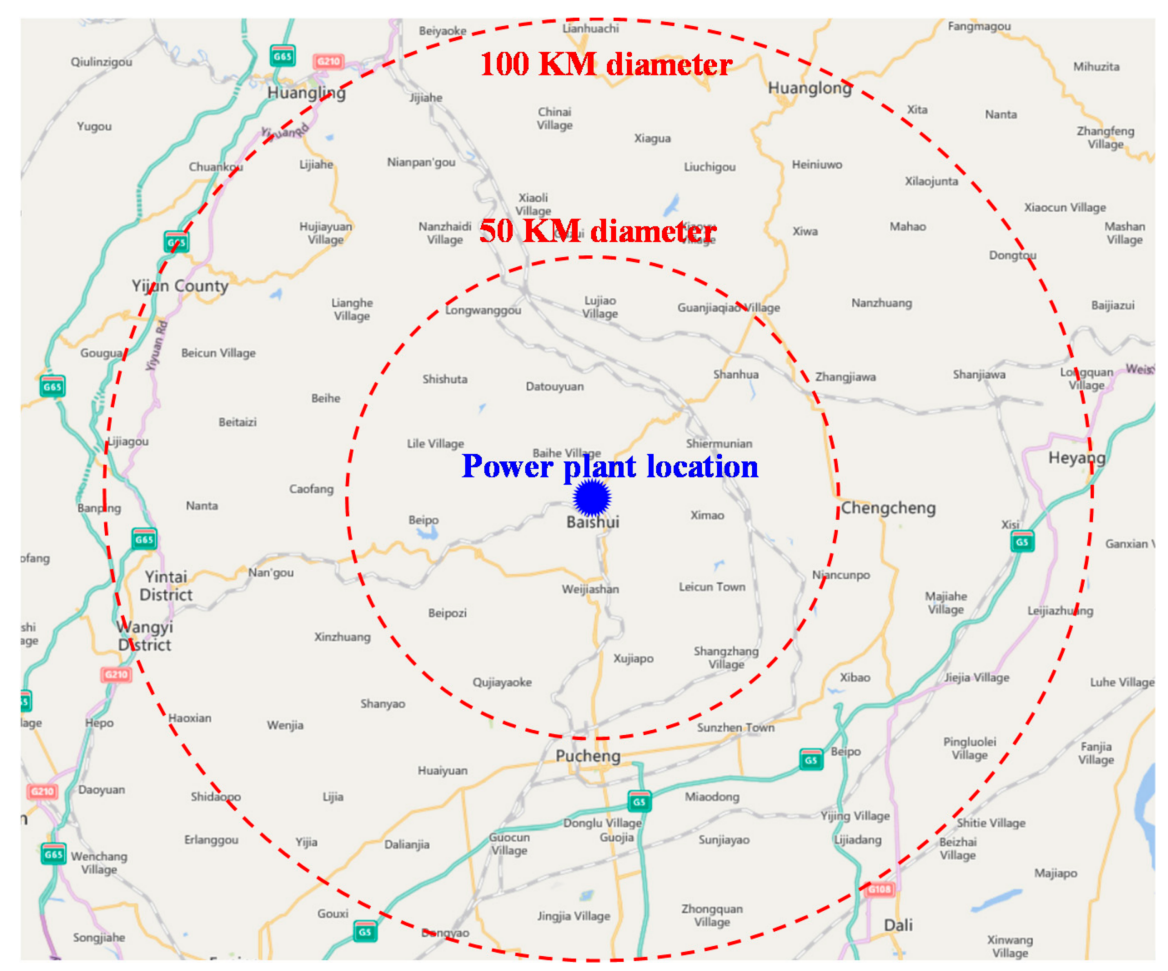

Figure 1. Power plant location and biomass collection area. 
Table 1. Available biomass resources in the area with collection diameter $100 \mathrm{~km}$ (unit: $\times 1000 \mathrm{ton}$ ).

\begin{tabular}{lcccc}
\hline $\begin{array}{l}\text { County } \\
\text { Name }\end{array}$ & $\begin{array}{c}\text { Food Crop Biomass } \\
(\times \mathbf{1 0 0 0} \text { ton })\end{array}$ & $\begin{array}{c}\text { Fruit Tree Biomass } \\
(\times \mathbf{1 0 0 0} \text { ton })\end{array}$ & $\begin{array}{c}\text { Others } \\
(\times \mathbf{1 0 0 0} \text { ton })\end{array}$ & $\begin{array}{c}\text { Total } \\
(\times \mathbf{1 0 0 0} \text { ton })\end{array}$ \\
\hline Baishui & 181.7 & 192.5 & 34.6 & 408.7 \\
Fuping & 420.0 & 63.0 & 40.3 & 523.3 \\
Hancheng & 147.0 & 35.7 & - & 182.7 \\
Chengcheng & 225.4 & 171.4 & 7.7 & 404.5 \\
Henyang & 315.0 & 182.0 & 35.0 & 532.0 \\
Dali & 217.0 & 140.0 & 117.6 & 474.6 \\
Huaxian & 151.7 & 21.0 & 113.4 & 286.1 \\
Huangling & 67.9 & 87.5 & - & 155.4 \\
Huanglong & 63.4 & 11.2 & - & 74.6 \\
Luochuan & 64.1 & 178.5 & - & 242.6 \\
Fuxian & 89.6 & 140.0 & - & 229.6 \\
Yijun & 136.5 & 122.5 & - & 259.0 \\
Wangyi & - & 7.0 & - & 7 \\
Yanliang & 99.2 & - & - & 99.2 \\
Pucheng & 231.0 & 141.8 & - & 372.8 \\
Total & 2409.4 & 1494.0 & 348.6 & 4252.0
\end{tabular}

Note: the available biomass resource is calculated by "Planting area (unit: acre)" $\times 0.5$ ton/acre $\times 0.7$, where 0.5 ton/acre means per acre planting area can produce 0.5 -ton biomass, and 0.7 is the collection efficiency.

Table 2. Proximate analysis and heating values of available biomass fuels.

\begin{tabular}{|c|c|c|c|c|c|}
\hline Biomass & $\mathrm{W}_{\mathrm{ad}} / \%$ & $\mathrm{~A}_{\mathrm{ar}} / \%$ & $\mathrm{~V}_{\mathrm{ar}} / \%$ & $\mathrm{FC}_{\mathrm{ar}} / \%$ & $\mathrm{Q}_{\text {net.ar }} \mathrm{MJ} / \mathrm{Kg}$ \\
\hline Bean stalk & 3.99 & 3.55 & 75.56 & 16.12 & 14.52 \\
\hline $\begin{array}{l}\text { Sorghum } \\
\text { stalk }\end{array}$ & 3.39 & 5.55 & 75.48 & 16.02 & 12.89 \\
\hline Corncob & 3.09 & 0.95 & 76.14 & 17.66 & 10.55 \\
\hline $\begin{array}{l}\text { Locust tree } \\
\text { branch }\end{array}$ & 3.77 & 1.73 & 77.01 & 15.60 & 15.37 \\
\hline $\begin{array}{l}\text { Apple tree } \\
\text { branch (wet) }\end{array}$ & 3.03 & 2.43 & 76.11 & 17.62 & 15.28 \\
\hline $\begin{array}{l}\text { Apple tree } \\
\text { branch (dry) }\end{array}$ & 3.49 & 1.24 & 76.01 & 16.76 & 10.21 \\
\hline
\end{tabular}

\section{Research Method}

\subsection{Biomass Co-Firing System}

The experimental setup of the mentioned biomass co-firing power plant is shown in Figure 2. First, the pulverized coal and biomass powder are mixed, which form a fuel mixture, and then are stored in the fuel tank. After this, it is supplied to the ball mill, where it is ground into a fine powder. Then it is passed through a coarse powder separator where the fine powder is sent into the fine powder separator while the coarse particles are recycled into the ball mills. The heavy particles from the fine powder separator are stored in the powder storehouse while the light particles are fed into the furnace through tertiary air. The induced draft fans are connected to the powder storehouse, which deliver the fine fuel particles to the furnace through primary air. Secondary air is also provided as an alternative to the primary air so to enhance combustion. In addition, separated over-fire air is supplied in the last section, as shown in Figure 2, to complete the combustion of remained unburned carbon and hydrocarbon radicles. The clear distribution pattern of different types of air is illustrated in Figure $2 b$.

\subsection{Fuel Properties}

The fuel properties of biomass co-firing fuel sampled from the storehouse are investigated by proximate analysis, ultimate analysis, and calorific value at different test conditions given in Table 3. The contents of N, C, and S of biomass are lower while $\mathrm{H}$ and $\mathrm{O}$ are higher, respectively, than that of pure pulverized coal. Moreover, biomass fuel's 
moisture and volatiles are much higher than pulverized coal, whereas the ash content is significantly lower than pulverized coal. Further, with the increase in biomass mixing ratio, the moisture content increased slightly. The small proportion of biomass mixing did not significantly increase the volatiles, but when the mixing balance reached $20 \%$, the volatiles increased significantly. Besides, the calorific value of biomass is substantially lower than that of coal. However, with the increase in the biomass-mixing ratio, the calorific value of the fuel from the pulverizing system (silo) only slightly reduced. The analysis revealed that the properties of fuel powder in co-firing cases are not significantly changes than that of $100 \%$ coal case, as shown in Table 3. Since it seemed that due to the low density of biomass particles, most biomass particles are separated in the fine-powder separator and passed into the furnace through the tertiary airports.

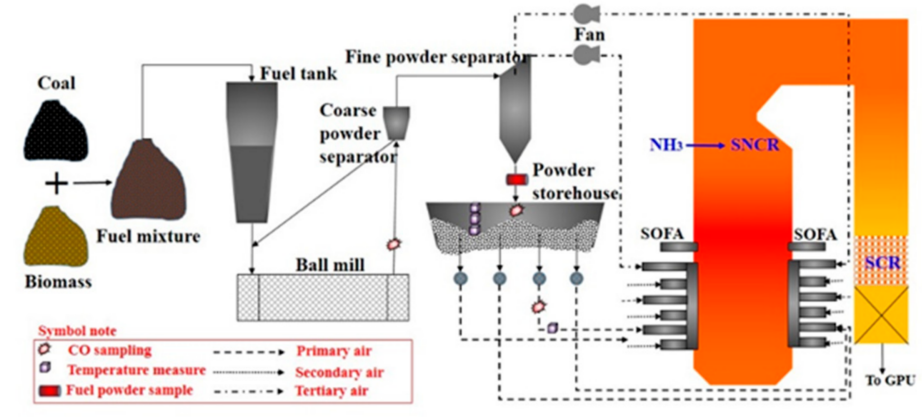

(a)

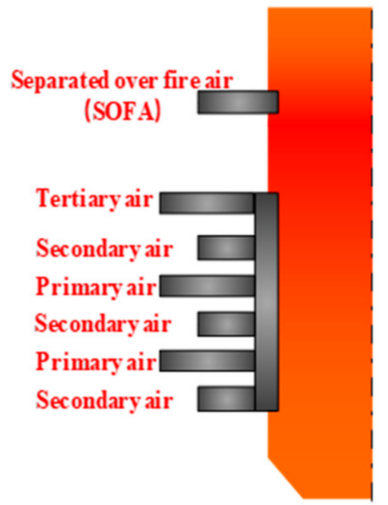

(b)

Figure 2. (a) Biomass co-firing system (b) burner port layout.

Table 3. Proximate and ultimate analysis of fuel used in biomass co-firing test.

\begin{tabular}{lcccccccccc}
\hline \multirow{2}{*}{ Condition } & \multicolumn{4}{c}{ Proximate Analysis (\%) } & \multicolumn{4}{c}{ Ultimate Analysis (\%) } & \multirow{2}{*}{$\mathbf{Q}_{\mathbf{g r}, \mathbf{d}} /$} \\
\cline { 2 - 10 } & $\mathbf{M}_{\mathbf{a d}}$ & $\mathbf{V}_{\mathbf{a d}}$ & $\mathbf{F C}_{\mathbf{a d}}$ & $\mathbf{A}_{\mathbf{a d}}$ & $\mathbf{C}_{\mathbf{d}}$ & $\mathbf{H}_{\mathbf{d}}$ & $\mathbf{O}_{\mathbf{d}}$ & $\mathbf{N}_{\mathbf{d}}$ & $\mathbf{S}_{\mathbf{d}}$ & $\mathbf{M J}_{\mathbf{K}} \mathbf{- 1}$ \\
\hline 100\% coal & 0.81 & 17.15 & 49.5 & 32.5 & 55.3 & 2.97 & 3.84 & 1.15 & 3.4 & 22.69 \\
5\% biomass & 0.89 & 16.22 & 48.9 & 33.9 & 54.2 & 2.87 & 3.26 & 1.14 & 3.5 & 23.18 \\
10\% biomass & 1.10 & 17.92 & 48.4 & 32.5 & 54.4 & 2.95 & 4.60 & 1.14 & 3.3 & 22.32 \\
20\% biomass & 1.05 & 23.9 & 43.0 & 32.0 & 55.5 & 2.99 & 4.03 & 1.14 & 3.1 & 22.55 \\
100\% biomass & 3.94 & 67.6 & 15.8 & 12.5 & 42.3 & 4.78 & 35.1 & 0.75 & 0.5 & 16.68 \\
\hline
\end{tabular}

\subsection{Experimental Procedure}

In the test, the pulverizing system, i.e., ball mill and powder storehouse, were running under negative pressure to feed the biomass and pulverized (co-fired fuel) into the furnace for combustion. Overall, four groups of tests were conducted:(1) pure pulverized coal combustion; (2) 5\% biomass mixing; (3) 10\% biomass mixing; (4) 20\% biomass mixing. First, the pure pulverized coal combustion test (1) was carried out and then followed by tests (2)-(4). Each test group was run twice; one with ammonia supply and the other without ammonia, to evaluate the efficiency of the SNCR process for $\mathrm{NO}_{\mathrm{x}}$ emission control. During experiments (1)-(4), the boiler operating load and other parameters kept stable. All of the test conditions are summarized in Table 4 . The measured parameters were the coal mill outlet temperature, fineness of the mixed fuel (coal + biomass) powder, the temperature of the different location in the powder storehouse, the temperature of the primary air, $\mathrm{CO}$ at the outlet of the mill and in the powder storehouse, unburned carbon in fly ash and slag, boiler efficiency, $\mathrm{NO}_{\mathrm{x}}$ emission, and the effect of co-firing on SNCR. Air staging was applied to analyze its impact on ignition, combustibility, and $\mathrm{NO}_{\mathrm{x}}$ emission. The design parameters of primary, secondary, and tertiary air are illustrated in Table 5. Mastersizer 2000 (Malvern Instrument Ltd., Malvern, UK) was used to measure the size distribution of the pulverized biomass particles from the outlet of mill F. Testo 350 (Testo Ltd., Lenzkirch, 
Germany) was used to detect the emission of gaseous emissions. An infrared thermometer 3iLRL3 (Raytek Ltd., Ashington, UK) was used to measure the furnace temperature.

Table 4. Test conditions.

\begin{tabular}{|c|c|c|c|c|c|c|}
\hline \multirow{2}{*}{ Condition } & \multirow{2}{*}{$\begin{array}{c}\text { Biomass } \\
\text { Ratio (wt.\%) }\end{array}$} & \multirow{2}{*}{$\begin{array}{c}\text { Primary Air } \\
\text { Temperature }\left({ }^{\circ} \mathrm{C}\right)\end{array}$} & \multicolumn{2}{|c|}{$\begin{array}{l}\text { Secondary Air } \\
\text { Temperature }\left({ }^{\circ} \mathrm{C}\right)\end{array}$} & \multirow{2}{*}{$\begin{array}{l}\text { Tertiary } \\
\text { Air } \\
\text { (On/Off) }\end{array}$} & \multirow{2}{*}{$\begin{array}{l}\text { Ammonia } \\
\text { (On/Off) }\end{array}$} \\
\hline & & & Left & Right & & \\
\hline 1 & 0 & 240 & 356 & 354 & On & Off \\
\hline 2 & 0 & 240 & 356 & 354 & On & On \\
\hline 3 & 5 & 224 & 349 & 348 & On & Off \\
\hline 4 & 5 & 224 & 349 & 348 & On & On \\
\hline 5 & 10 & 232 & 346 & 345 & On & Off \\
\hline 6 & 10 & 232 & 346 & 345 & On & On \\
\hline 7 & 20 & 224 & 342 & 345 & On & Off \\
\hline 8 & 20 & 224 & 342 & 345 & On & On \\
\hline
\end{tabular}

Table 5. Designed parameters of primary, secondary, and tertiary air.

\begin{tabular}{lccc}
\hline Air Type & Primary Air (with Coal) & Secondary Air & Tertiary Air \\
\hline Air ratio $(\%)$ & 25 & 56 & 19 \\
Air velocity $(\mathrm{m} / \mathrm{s})$ & 25 & 45 & 55 \\
Temperature $\left({ }^{\circ} \mathrm{C}\right)$ & 263 & 335 & 120 \\
\hline
\end{tabular}

\section{Results and Discussion}

This section will present the results of the safety study on biomass co-firing pulverizing and powder-storage systems, as well as the effects of biomass co-firing on the pulverizing system, furnace efficiency, and $\mathrm{NO}_{\mathrm{x}}$ efficiency, respectively.

\subsection{Safety Analysis on Pulverizing and Powder-Storage System Used for Biomass Co-Firing}

Two key parameters, namely carbon monoxide (CO) concentration and temperature, were analyzed at different locations of the pulverizing device, powder storehouse, and in the primary air to assess the safety of pulverizing and powder-storage systems used for biomass co-firing. $\mathrm{CO}$ is a readily combustible gas that can easily be generated in fuel-rich conditions, while temperature is the primary determinant of fuel autoignition. In this regard, the $\mathrm{CO}$ concentration at different points in the pulverizing system, i.e., at the outlet of the coal mill, the upper space of the powder storehouse, and in the primary air, respectively, were tested, and the results are shown in Figure 3a,b respectively. In addition, the temperatures at three locations in the powder storehouse and in the primary air were measured to evaluate the safety status of the pulverizing system after mixing the biomass with coal; the results are summarized in Figure $4 \mathrm{a}, \mathrm{b}$ respectively. The locations of different measurement points are shown in Figure $2 a$. It can be seen from the test results that, despite the addition of biomass fuel, the $\mathrm{CO}$ concentration at the outlet of the coal mill and the upper part of the powder bin is still very low (the highest is only 6 ppm, Figure $3 a)$. Further, the $\mathrm{CO}$ concentration in hot primary air is in the range of 115-173 ppm, which is comparable with the value of $130 \mathrm{ppm}$ in a 100\% coal case (Figure 3b). Moreover, the powder bin's temperature at all three points, the top, middle, and bottom, decreased with the increase of the biomass mixing proportion, and the maximum temperature was less than $75^{\circ} \mathrm{C}$, as illustrated in Figure 4 a. Similarly, the temperature of the primary air-coal mixture and secondary air at the left and right side of the furnace depicted in Figure $4 \mathrm{~b}$ is also less than the temperature of $100 \%$ coal stream. 


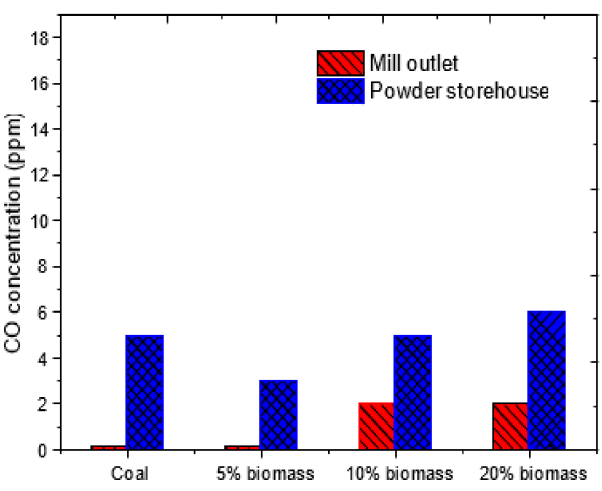

(a)

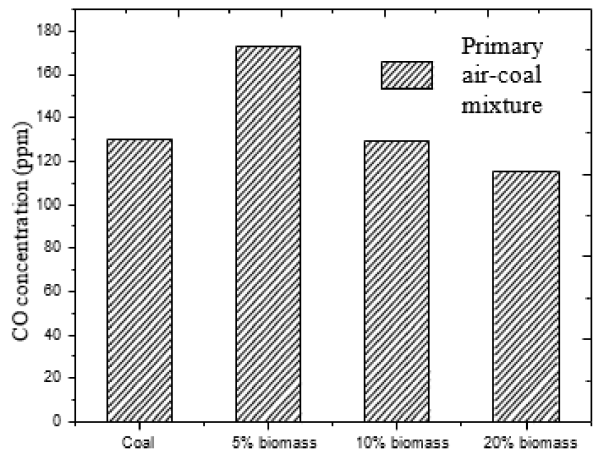

(b)

Figure 3. CO concentration in (a) pulverizing, powder storage, and (b) transporting system.

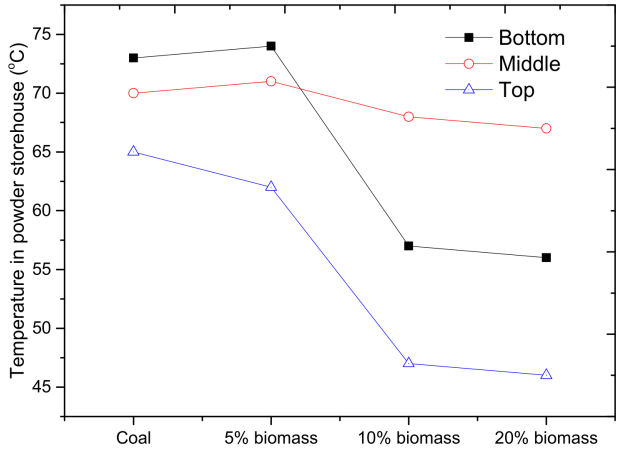

(a)

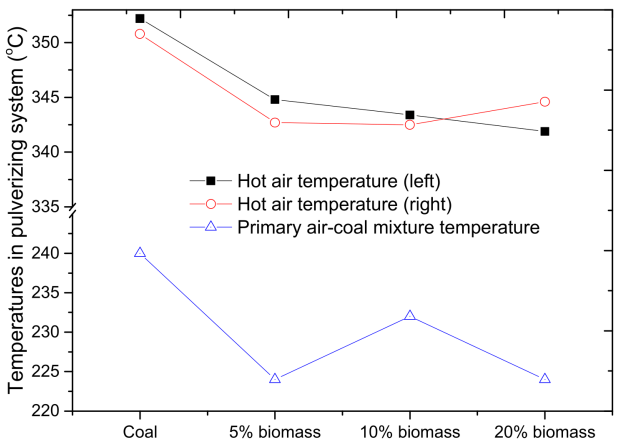

(b)

Figure 4. Temperatures in (a) powder-storage and (b) transporting system.

\subsection{Effect of Biomass Co-Firing on Pulverizing System}

In this experiment, biomass co-firing affected the performance of the pulverizing system to a certain degree. This power plant pulverizing system is comprised of two main raw mills, R90 and R200. The names are given based on the particle size produced by each mill, such that R90 and R200 pulverizing raw fuel into 90 and 200 micrometers ( $\mu \mathrm{m})$ sizes, respectively. By increasing the biomass co-firing ratio from 0 to $20 \mathrm{wt} \%$, the values of fuel powder fineness produced by R90 and R200 increased from $17.5 \%$ and $1.0 \%$ to $19 \%$ and $4 \%$, respectively, as shown in Figure 5a. Likewise, the particle size at the outlet of D50 and D90 increased from $30 \mu \mathrm{m}$ and $100 \mu \mathrm{m}$ to $40 \mu \mathrm{m}$ and $160 \mu \mathrm{m}$, respectively, as illustrated in Figure 5b.

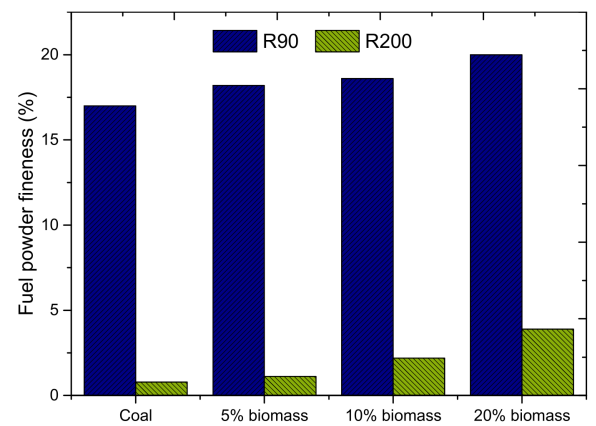

(a)

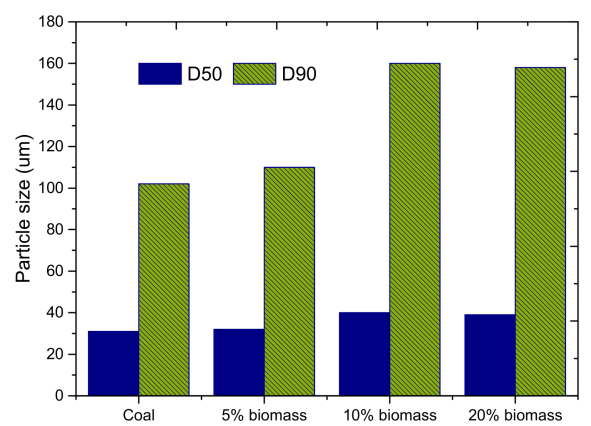

(b)

Figure 5. Particle sizes at different biomass co-firing ratios; (a) fuel fineness \%, and (b) average particle sizes. 


\subsection{Effect of Biomass Co-Firing on Furnace Efficiency}

It was observed during the experiment that the blending of biomass had a certain effect on the burnout of the fuel. As shown in Table 6 with the increase in the biomass co-firing ratio from 0 to $20 \mathrm{wt} . \%$, the unburned carbon content (UBCs) in fly ash and slag rose. The rise in UBCs was due to the drop-in furnace temperature, as can be seen from the exhaust temperature in Table 6 . Consequently, the furnace efficiency is slightly reduced with the increasing blending ratio of biomass with co-firing coal.

Table 6. Effects of biomass co-firing on boiler efficiency.

\begin{tabular}{lcccc}
\hline Conditions & $\begin{array}{c}\mathbf{1} \text { UBC in } \\
\text { Fly Ash (\%) }\end{array}$ & $\begin{array}{c}\text { UBC in Bottom } \\
\text { Slag (\%) }\end{array}$ & $\begin{array}{c}\text { Exhaust } \\
\text { Temperature }\left({ }^{\circ} \mathbf{C}\right)\end{array}$ & $\begin{array}{c}\text { Furnace } \\
\text { Efficiency (\%) }\end{array}$ \\
\hline 100\% coal & 4.71 & 11.48 & 138.4 & 90.88 \\
$5 \%$ biomass & 4.68 & 14.06 & 139.2 & 90.82 \\
$10 \%$ biomass & 5.77 & 15.96 & 135.5 & 90.09 \\
$20 \%$ biomass & 5.16 & 15.99 & 134.1 & 90.11 \\
\hline
\end{tabular}

${ }^{1} \mathrm{UBC}$ : unburned carbon content.

\subsection{Effect of Biomass Co-Firing on $\mathrm{NO}_{x}$ Emissions}

The effect of biomass co-firing on $\mathrm{NO}_{x}$ emissions was studied, and the results are illustrated in Figure 6. The tests were conducted on the four condition types (coal, $5 \%$ biomass, $10 \%$ biomass, and $20 \%$ biomass) with and without supplying ammonia (SNCR process). It was observed that the co-firing of biomass was beneficial for reducing $\mathrm{NO}_{x}$ even without applying the SNCR process. As shown in Figure $6 \mathrm{a}$, at $20 \mathrm{wt} . \%$ biomass co-firing ratios, the $\mathrm{NO}_{\mathrm{x}}$ emission before the De- $\mathrm{NO}_{\mathrm{x}}$ system decreased by $24.5 \%$, as compared to the $100 \%$ coal combustion. It can also be seen from Figure 6 a that $\mathrm{NO}_{\mathrm{x}}$ reduction further increased by providing ammonia (SNCR process) [22]. As shown in Figure 6b, the overall de- $\mathrm{NO}_{\mathrm{x}}$ efficiency by using the SNCR in co-firing biomass steadily increased from $56 \%$ to $71 \%$, as the biomass fraction increased from $0 \%$ to $20 \%$.

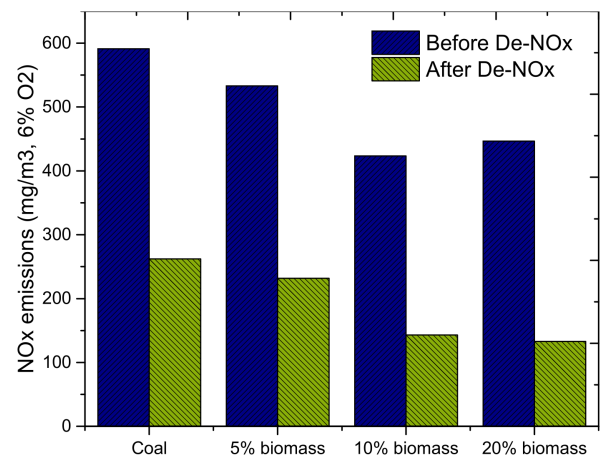

(a) NOx emission

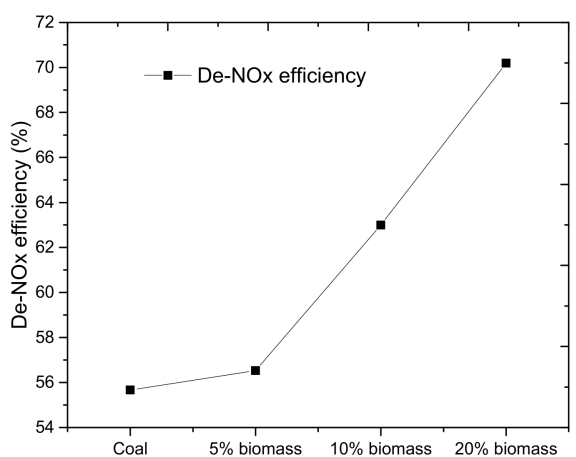

(b) De-NOx efficiency

Figure 6. Effect of biomass co-firing on (a) $\mathrm{NO}_{\mathrm{x}}$ emission and (b) de- $\mathrm{NO}_{\mathrm{x}}$ efficiency.

\section{Discussion}

Co-firing biomass with coal raises some safety issues that involve the additional potential for fire and explosion. Biomass is much more reactive than the majority of coal, pet coke, and anthracite. It is therefore important to evaluate the risk of explosion for such mixtures. Two main parameters, i.e., $\mathrm{CO}$ and temperature, were evaluated to ensure safety with respect to fire and explosion. Results in Section 3.1 illustrate that the $\mathrm{CO}$ concentration in the coal mill and powder storage was still in the safe zone even with the different percentages of biomass co-firing with coal. Moreover, the temperature fell by increasing the mixing proportion of biomass in the co-firing system. There are two main reasons for this phenomenon: the relatively high moisture content in the mixed biomass and the low calorific value of the biomass as compared to pure coal [12]. This means that there is no risk 
of auto-ignition by mixing the biomass with coal up to $20 \%$, and it has no risk regarding safety when operated with biomass co-firing.

The size of the pulverized biomass particles depends primarily on the type of mill used, and it is costly to manufacture small fibrous biomass particles. As a consequence, it is expected that the large particles present in the biomass supply would influence the dynamics of combustion [23]. Results from Section 3.2 portray that the particle size from the pulverizing system continuously increased with the increasing blending ratio of biomass with coal co-firing. The increase in size, with the increasing biomass proportion, is due to the tenacious fibrous and non-friable nature of biomass [24]. Due to the difficulty of grinding the biomass particles into required fineness, it rarely decreased the output performance of the pulverizing system. Based on the experiment results, it is suggested that mixing biomass up to $20 \%$ is appropriate in terms of the fineness of the co-firing fuel. However, if the blending ratio exceeds $20 \%$, the pulverizing system's performance will suffer.

Section 3.3 concludes that the furnace efficiency slightly decreased with the increasing blending ratio of biomass with coal co-firing. The volatile content in the biomass compared to pure coal is significantly larger. In addition, the inherent fibrous structure, the irregular biomass particle shape, higher aspect ratio, the lower energy density, and lower calorific value were all main causes of UBCs and lower temperature [25]. With the biomass co-firing method, the rise in UBCs and a slight decrease in exhaust temperature contributed to a decline in furnace efficiency of up to $7.0 \mathrm{wt} . \%$. A similar result was also noticed by Y. Huang et al. [26], who portrayed that the net furnace efficiency had declined with the increase of biomass fraction as a co-firing with coal. They concluded that the efficiency on thermal bases decreased by up to $2.3 \%$, with the biomass fraction rising from $0 \%$ to $40 \%$ relative to the base case ( $100 \%$ coal). Therefore, it is concluded that the fraction of biomass in co-firing up to $20 \%$ is feasible, but greater than this percentage; it would severely affect the performance of the furnace $[7,13,27]$.

It is illustrated in Section 4.4 that co-firing biomass with coal is very beneficial in reducing the $\mathrm{NO}_{\mathrm{x}}$. There are various potential explanations for the reduction of $\mathrm{NO}_{\mathrm{x}}$ when biomass is co-fired with coal. The first one is generally the low contents of nitrogen in the biomass as compared to pure coal [28]. The second is the high content of volatile in biomass as compared to pure coal. Furthermore, at the beginning of biomass combustion, oxygen is rapidly consumed by a large quantity of volatiles produced during the devolatilization phase, which generates a reduced environment that is very suitable for the reduction of $\mathrm{NO}_{\mathrm{x}}$. In addition, radicals such as $\mathrm{CH}_{\mathrm{i}}$ have been produced in large quantities due to the high content of volatiles in biomass, and these radicals have been highly efficient in the reduction of $\mathrm{NO}$ to $\mathrm{N}_{2}[28,29]$. In addition, air staging is also one of the main reasons for the reduction of $\mathrm{NO}_{\mathrm{x}}$. The basic principle of air staging for $\mathrm{NO}_{\mathrm{x}}$ control is to generate a fuel-rich condition in the primary section of the furnaces, where the hydrocarbon radicles can easily consume the oxygen of $\mathrm{NO}_{x}$ and reduced it into the $\mathrm{N}_{2}$ [30]. Then staged overfire air is supplied above the primary zone to complete burnout of the remaining traces of fuel.

Further, the de- $\mathrm{NO}_{x}$ efficiency of the SNCR process is enhanced by increasing the biomass blending ratio from $0 \%$ to $20 \%$. This is due to the synergistic effect of both the cofired biomass and the SNCR process leading to a better de- $\mathrm{NO}_{x}$ efficiency [31]. In addition, the biomass also contains high alkali metals, such as potassium, calcium, and sodium, which could have a catalytic effect in enhancing the performance of the SNCR [32,33]. J. Hoa et al. [34] illustrated in their experimental work that the $\mathrm{Na} / \mathrm{K}$ additive had a prominent enhancement effect in $\mathrm{NO}_{\mathrm{x}}$ reduction by SNCR and that the enhancement effect was in the order of $\mathrm{Na}_{2} \mathrm{CO}_{3}>\mathrm{KCl}>\mathrm{NaCl}$. The promotional effect of alkali metal is explained by the fact that it accelerates the production of more reactive $\mathrm{OH}$ radicles during the SNCR process, which improves the SNCR performance by mainly increasing the production rate of $\mathrm{NH}_{2}$ radicals [35]. 


\section{Conclusions}

In this study, biomass direct co-firing was carried out in a $55 \mathrm{MW}$ tangentially fired pulverized coal furnace. The effects of biomass co-firing on safety, the performance of the pulverizing system, furnace efficiency, and pollutant emissions were studied. The main conclusions are:

1. $\mathrm{CO}$ and temperature were measured at different plant locations for the safety purposes of the biomass co-fired process. Both parameters were safe and concluded that the blending of biomass fuel with less than $20 \%$ of coal has no issue with respect to auto-ignition.

2. The pulverized size of the co-fired fuel was increasing with the increasing biomass co-firing ratio due to the tenacious fibrous and non-friable nature of biomass. Due to the difficulty of grinding the biomass particles into required fineness, it rarely decreased the output performance of the pulverizing system.

3. The increase in UBCs and the slight decrease in exhaust temperature contributed to a decrease in furnace efficiency of up to $7.0 \mathrm{wt} . \%$ with the biomass co-firing method. It is concluded that up to $20 \%$ of the fraction of biomass in co-firing is feasible, but greater than this percentage will severely affect the furnace efficiency.

4. The co-firing of biomass is supportive in the enhancement of the $\mathrm{NO}_{\mathrm{x}}$ reduction and could significantly increase the thermal de- $\mathrm{NO}_{\mathrm{x}}$ efficiency.

Author Contributions: Conceptualization, X.W., Z.U.R., and H.T.; methodology, X.W., Z.U.R., and H.T.; validation, X.W., Z.U.R., Z.L., Y.Z., and H.T.; formal analysis, X.W., Z.U.R., Z.L., Y.Z., R.R., S.D., L.Z., and T.H; investigation, X.W., Z.U.R., Z.L., Y.Z., R.R., S.D., L.Z., and H.T.; resources, X.W., and H.T.; writing-original draft preparation, X.W. and Z.U.R.; writing-review and editing, X.W. and Z.U.R.; supervision, X.W. and H.T.; project administration, X.W., and H.T.; funding acquisition, X.W., L.Z., and H.T. All authors have read and agreed to the published version of the manuscript.

Funding: This research was funded by the National Key Research and Development Program of China (No. 2020YFC1910000), the National Natural Science Foundation of China (Nos. 51761125012), the Key Scientific and Technological Projects in Henan Province (182102410053) and the Natural Science Basic Research Plan in Shaanxi Province of China (2021JC-03).

Institutional Review Board Statement: Not applicable.

Informed Consent Statement: Not applicable.

Data Availability Statement: Data reported within the article.

Acknowledgments: The authors gratefully acknowledge the National Key Research and Development Program of China (No. 2020YFC1910000), the National Natural Science Foundation of China (Nos. 51761125012), the Key Scientific and Technological Projects in Henan Province (182102410053) and the Natural Science Basic Research Plan in Shaanxi Province of China (2021JC-03).

Conflicts of Interest: The authors declare no conflict of interest.

\section{References}

1. Li, M.; Wang, D.; He, S.; Shao, Z.; Shen, Y. Experimental study on foaming properties of anion-cation compound foaming agent to prevent coal spontaneous combustion. Colloids Surf. A Physicochem. Eng. Asp. 2019, 581, 123847.

2. Chowdhury, S.; Mamun, S.; Maruffuzzaman, M.; Lein, W.; Jhonson, S. Biomass co-firing technology with policies, challenges, and opportunities: A global review. Renew. Sustain. Energy Rev. 2017, 78, 1089-1101.

3. Tillman, D.; Duong, D.; Harding, N. Chapter 4-Blending Coal with Biomass: Cofiring Biomass with Coal. In Solid Fuel Blending; Butterworth-Heinemann: Boston, MA, USA, 2012; pp. 125-200.

4. Truong, A.H.; Patrizio, P.; Leduc, S.; Kraxner, F.; Ha, D.; Minh, H.D. Reducing emissions of the fast growing Vietnamese coal sector: The chances offered by biomass co-firing. J. Clean. Prod. 2019, 215, 1301-1311.

5. Smith, J.S.; Safferman, S.I.; Saffron, C. Development and application of a decision support tool for biomass co-firing in existing coal-fired power plants. J. Clean. Prod. 2019, 236, 117375.

6. Sajdak, M.; Kmiec, M.; Micek, B.; Harabak, J. Determination of the optimal ratio of coal to biomass in the co-firing process: Feed mixture properties. Int. J. Environ. Sci. Technol. 2019, 16, 2989-3000. 
7. Gil, M.V.; Rubiera, F. Coal and Biomass Cofiring: Fundamentals and Future Trends. In New Trends in Coal Conversion; Elsevier: Amsterdam, The Netherlands, 2019; pp. 117-140.

8. Sami, M.; Annamalai, K.; Wooldridge, M. Co-firing of coal and biomass fuel blends. Prog. Energy Combust. Sci. 2001, 27, 171-214.

9. Kazagic, A.; Smajevic, I. Synergy effects of co-firing wooden biomass with Bosnian coal. Energy 2009, 34, $699-707$.

10. Paiman, M.E.S.; Hamzah, N.S.; Idris, S.S.; Rahman, N.A.; Ismail, K. Synergistic Effect of Co-Utilization of Coal and Biomass Char: An Overview. In IOP Conference Series: Materials Science and Engineering; IOP Publishing: Selangor, Malaysia, 2018; Volume 358, p. 012003.

11. Hodžić, N.; Metović, S.; Kazagic, A. Effects on $\mathrm{NO}_{\mathrm{x}}$ and $\mathrm{SO}_{2}$ Emissions during Co-Firing of Coal with Woody Biomass in Air Staging and Reburning. Int. J. Renew. Energy Dev. 2018, 7, 1.

12. Wang, X.; Tan, H.; Niu, Y.; Pourkashanian, M.; Ma, L.; Chen, E.; Liu, Y.; Liu, Z.; Xu, T. Experimental investigation on biomass co-firing in a $300 \mathrm{MW}$ pulverized coal-fired utility furnace in China. Proc. Combust. Inst. 2011, 33, 2725-2733.

13. Chowdhury, M.S.R.; Azad, A.K.; Karim, M.R.; Naser, J.; Bhuiyan, A.A. Reduction of GHG emissions by utilizing biomass co-firing in a swirl-stabilized furnace. Renew. Energy 2019, 143, 1201-1209.

14. Chen, L.; Li, X.; Wen, W.; Jia, J.; Li, G.; Deng, F. The status, predicament and countermeasures of biomass secondary energy production in China. Renew. Sustain. Energy Rev. 2012, 16, 6212-6219.

15. Kinoshita, T.; Ohki, T.; Yamagata, Y. Woody biomass supply potential for thermal power plants in Japan. Appl. Energy 2010, 87, 2923-2927.

16. Xingang, Z.; Jieyu, W.; Xiaomeng, L.; Tiantian, F.; Pingkuo, L. Focus on situation and policies for biomass power generation in China. Renew. Sustain. Energy Rev. 2012, 16, 3722-3729.

17. Xingang, Z.; Zhongfu, T.; Pingkuo, L. Development goal of $30 \mathrm{GW}$ for China's biomass power generation: Will it be achieved? Renew. Sustain. Energy Rev. 2013, 25, 310-317.

18. Kazagic, A.; Hodzic, N.; Metovic, S. Co-combustion of low-rank coal with woody biomass and miscanthus: An experimental study. Energies 2018, 11, 601.

19. Baxter, L. Biomass-Coal Cofiring: An Overview of Technical Issues. In Solid Biofuels for Energy; Springer: Berlin/Heidelberg, Germany, 2011; pp. 43-73.

20. Choi, M.; Li, X.; Kim, K.; Sung, Y.; Choi, G. Detailed in-furnace measurements in a pulverized coal-fired furnace with combined woody biomass co-firing and air staging. J. Mech. Sci. Technol. 2018, 32, 4517-4527.

21. Luo, R.; Zhou, Q. Combustion kinetic behavior of different ash contents coals co-firing with biomass and the interaction analysis. J. Therm. Anal. Calorim. 2017, 128, 567-580.

22. Rahman, Z.U.; Wang, X.; Zhang, J.; Jakov, B.; Millan, V.; Tan, H. Kinetic study and optimization on SNCR process in pressurized oxy-combustion. J. Energy Inst. 2020, 94, 263-271.

23. Gubba, S.R.; Ma, L.; Pourkashanian, M.; Williams, A. Influence of particle shape and internal thermal gradients of biomass particles on pulverised coal/biomass co-fired flames. Fuel Process. Technol. 2011, 92, 2185-2195.

24. Basu, P. Biomass Gasification, Pyrolysis and Torrefaction: Practical Design and Theory; Academic Press: Cambridge, MA, USA, 2018.

25. Rokni, E.R.; Xiaohan, P.; Aidin, L.; Yiannis, A. Emissions of $\mathrm{SO}_{2}, \mathrm{NO}_{\mathrm{x}}, \mathrm{CO}_{2}$, and $\mathrm{HCl}$ from co-firing of coals with raw and torrefied biomass fuels. Fuel 2018, 211, 363-374.

26. Huang, Y.; Mcilveen, W.D.; Rezvani, S.; Wang, Y.D.; Hewitt, N.; Williams, B.C. Biomass co-firing in a pressurized fluidized bed combustion (PFBC) combined cycle power plant: A techno-environmental assessment based on computational simulations. Fuel Process. Technol. 2006, 87, 927-934.

27. Yin, C. Biomass Co-Firing. In Biomass Combustion Science, Technology and Engineering; Elsevier: Amsterdam, The Netherlands, 2013; pp. 84-105.

28. Niksa, S.; Liu, G.; Felix, L.; Vann, B.P.; Douglas, M.B. Predicting NO $\mathrm{x}_{\mathrm{x}}$ emissions from biomass cofiring. In Proceedings of the 28th International Technical Conference on Coal Utilization and Fuel Systems, Clearwater, FL, USA, 9-13 March 2003.

29. Wang, Y.; Wang, X.; Hu, Z.; Li, Y.; Deng, S.; Niu, B.; Tan, H. NO emissions and combustion efficiency during biomass co-firing and air-staging. BioResources 2015, 10, 3987-3998.

30. Sung, Y.; Lee, S.; Kim, C.; Jun, D.; Moon, C.; Choi, G.; Kim, D. Synergistic effect of co-firing woody biomass with coal on $\mathrm{NO}_{\mathrm{x}}$ reduction and burnout during air-staged combustion. Exp. Therm. Fluid Sci. 2016, 71, 114-125.

31. Daood, S.S.; Javed, M.T.; Gibbs, B.M.; Nimmo, W. $\mathrm{NO}_{\mathrm{x}}$ control in coal combustion by combining biomass co-firing, oxygen enrichment and SNCR. Fuel 2013, 105, 283-292.

32. Savolainen, K. Co-firing of biomass in coal-fired utility boilers. Appl. Energy 2003, 74, 369-381.

33. Jaworek, A.; Jędrusik, M.; Świerczok, A.; Czech, T.; Sobczyk, A.T.; Lackowski, M. Biomass co-firing. New challenge for electrostatic precipitators. Int. J. Plasma Environ. Sci. Technol. 2011, 5, 161-167.

34. Yu, W.; Lu, P.; Hao, J.; Zhang, Y.; Zhu, X. The effects of Na/K additives and flyash on NO reduction in a SNCR process. Chemosphere Environ. Toxicol. Risk Assess. 2015, 122, 213-218.

35. Han, K.; Lu, C. Kinetic model and simulation of promoted selective non-catalytic reduction by sodium carbonate. Chin. J. Chem. Eng. 2007, 15, 512-519. 